\title{
A REVIEW: AQUILARIA SPECIES AS POTENTIAL OF PHARMACOLOGICAL
}

\author{
Nelly Marliani \\ Institut Pertanian Bogor \\ nelly_marliani@apps.ipb.ac.id
}

\begin{abstract}
One of the plants that is rich in benefits is from the genus Aquilaria spp. which is known to be able to produce agarwood resin. This genus includes 47 species, of which the four main species are Aquilaria malaccensis, Aquilaria subintegra, Aquilaria crassna and Aquilaria sinensis. Aquilaria species are known to have a wide spectrum of pharmacological activity and have been reported in many studies, including activity, anticancer, anti-inflammatory, AChE inhibitor (Acetylcholinesterase), anti-proliferative, and antidiabetic. The aim of this review is to expand information on the pharmacological activity of various Aquilaria species that can support future studies in the medical field of medicine.
\end{abstract}

Keywords: Aquilaria, pharmacological, natural.

Received 24 December 2020 Accepted 23 July 2021

\section{INTRODUCTION}

Aquilaria is a tree native to the rainforests of Southeast Asia and belongs to the Thymelaeaceae family [4], of which the genus Aquilaria spp. this includes 47 species, and 22 of them are included in the plant list. Some of the known species including Aquilaria malaccensis, Aquilaria subintegra, Aquilaria crassna, and Aquilaria sinensis [4] are used for therapeutic purposes as a traditional medical treatment of gout, headache, arthritis, cough, vomiting, asthma, leprosy and anorexia [10]. The aquilaria tree is known to produce a fragrant agarwood resin and is used in perfumes. This type of tree is found in many countries in the oriental region such as Indonesia, Malaysia, Thailand, India, Laos, and China [8]. In addition, Aquilaria extract has also been reported to have anticancer activity [9,11,14], antiinflammatory [1], antioxidant [3,9,14], and antidiabetic [14] which have been demonstrated in many in vivo and in vitro models. Therefore, the pharmacological effects of Aquilaria with different species and tree parts have different and similar pharmacological properties. This review will focus on the pharmacological effects for the 4 main species mentioned, a brief overview of the preparation methods and a discussion on the evaluation of their pharmacological properties.

\section{Aquilaria malaccensis}

Aquilaria malaccensis is one of the species of Aquilaria [7]. The leaves are known to have antioxidant activity. In the research of Batubara et al., (2020) [3] concerning the antioxidant activity of Aquilaria malaccensis leaves. Extraction of sample using maceration method, leaf ethanol extract followed by phytochemical tests to determine the content of secondary metabolites compounds. The antioxidant test was determined by the activity of free radical scavenging against 1,1-diphenyl-2-picrylhydrazyl (DPPH) with the percentage of free radical reduction parameters at different concentrations (40,60, 80, and $100 \mathrm{ppm}$ ) and inhibitory concentration values (IC50). Based on these studies, the results indicated the presence of 
secondary metabolites of alkaloids, steroids, triterpenoid, saponins, flavonoids, and tannins. The highest antioxidant activity of the ethanol extract of Aquilaria malaccensis leaves was $27.807 \pm 4.630$ ppm [3].

On the other hand, Apridamayanti et al., (2018) [1] reported that Aquilaria malaccensis has core-inflammatory activity. Leaf powder extraction by maceration method using ethanol solvent and concentration using a rotary evaporator. The anti-inflammatory potential of the ethanol extract of Aquilaria malaccensis leaves was evaluated using an in vivo model, using the carrageenan-induced leg edema method of rats. Measurement of the volume of the test animal's feet using a plestimometer containing mercury. The ethanol extract of Aquilaria malaccensis L. showed statistically significant inflammatory activity at a dose of $180 \mathrm{mg} / \mathrm{kg}$ of $37.9 \%$ [8]. Another in vitro study showed that the extract from Aquilaria malaccensis leaves had the highest anti-inflammatory activity which inhibited more than $50 \%$ of heatinduced protein denaturation with Soxhlet ethanol extract (ALEXB) [5].

\section{Aquilaria sinensis}

Aquilaria sinensis is best known for its wood resin or gaharu. Gaharu as an incense is widely used in oriental areas such as Thailand and Taiwan. This plant has various pharmacological activities. One of them was reported by Liu et al., (2018) [9] which evaluated the antioxidant activity and cytotoxicity of Aquilaria sinensis. Aquilaria sinensis stem samples were repeatedly extracted with $\mathrm{MeOH}$. Phytochemical compounds were isolated and analyzed by IR, UV, ESI-MS, 1HNMR, AND 13C NMR, then tested for their anti-proliferative and antioxidant activity based on the DPPH test (2,2-diphenyl-1-picrylhydrazyl) and the MTT test to determine the antiproliferative activity. The content of flavonoids 5-hydroxy-7,3 ', 4'trimethoxiflavones was effective against DPPH radicals at a concentration of $10 \mathrm{mM}$ with activity of $20.68 \pm 5.50 \%$. In the anti-proliferative activity of the compounds tested in A375 cells after 24 hours treatment, cells were treated with 5-hydroxy-7,3 ', 4'-trimethoxiflavone at concentrations of 10,50 , and $100 \mu \mathrm{M}$. These compounds showed significant inhibitory power at a concentration of $100 \mu \mathrm{M}$ in A375 cells, namely $68.00 \pm 1.33 \%$ of the cell survival rate.

\section{Aquilaria subintegra}

The leaves of the Aquilaria subintegra plant are claimed to be effective in the treatment of Alzheimer's disease by traditional Malaysian Malay practitioners [2]. In the study of Bahrani et al., (2014) [2] reported that extracts from the leaves and stems of Aquilaria subintegra can be used as a natural acetylcholinesterase (AChE) inhibitor as an alternative treatment for Alzheimer's Disease (AD). Extraction and analysis of compounds from the leaves and stems of Aquilaria subintegra with Thin Layer Chromatography (TLC) and LCMS-MS methods, where TLC results showed alkaloids and phenols, while LCMS-MS analysis showed that the stem extract contained kaempferol. The effect of chloroform extracts of leaves and stems and kaempferol was determined in Radial Arm Maze (RAM) after oral administration in ICR of male and female mice with valium memory impairment. Administration of kaempferol in mice significantly reduced the number of repeated entries into the labyrinth arm in males and females. Kampferol is one of the flavonoids with high AChE inhibitory activity. The AChE inhibitory activities of chloroform extracts of leaves and stems and kaempferol were $80 \%$, 93\%, and $85.8 \%$, respectively. The inhibition of AChE by extracts from Aquilaria subintegra can be caused by the presence of kaempferol, so this extract is safe to use as a natural AChE inhibitor in an alternative treatment for $\mathrm{AD}$.

Another study shows the potential of Aquilaria subintegra fruit extract as an anticancer drug. Aquilaria subintegra fruit and seed extraction using methanol, ethanol and $n$-hexane as solvents. The extracts were individually treated against avorium, breast and colorectal cancer cells for 72 hours. The cell percentage and maximum inhibitory concentration (IC50 value) used the sulforhodamine B-test. Fruit ethanol extract had the highest anticancer activity, namely IC50 $<0.1 \mu \mathrm{g} \mathrm{mL}^{-1}$ while the other extracts were inactive (IC50> $100 \mu \mathrm{g} \mathrm{mL}^{-1}$ ). Based 
on the results of chemical profile analysis using HPLC showed the presence of mangiferin in fruit extracts which was active when tested in each cancer cell line [11]. Table 1 summarizes the pharmacological effects of the four species of Aquilaria spp.

Table 1. Effects of pharmacological activity of Aquilaria spp.

\begin{tabular}{|c|c|c|c|c|c|}
\hline Species & Extracts & $\begin{array}{l}\text { Plant } \\
\text { Section }\end{array}$ & $\begin{array}{l}\text { Pharmacological } \\
\text { Effects }\end{array}$ & Extraction Methods & References \\
\hline \multirow[t]{2}{*}{$\begin{array}{l}\text { Aquilaria } \\
\text { malaccensis }\end{array}$} & Ethanol extract & Leaves & Antioxidant & $\begin{array}{l}\text { Maceration with ethanol } \\
\text { solvents }\end{array}$ & [3] \\
\hline & Ethanol extract & Leavers & Anti-inflammatory & $\begin{array}{l}\text { Maceration of leaf } \\
\text { powder with ethanol } \\
\text { solvent and } \\
\text { concentration using a } \\
\text { rotary evaporator }\end{array}$ & [1] \\
\hline $\begin{array}{l}\text { Aquilaria } \\
\text { sinensis }\end{array}$ & $\begin{array}{l}\text { Flavonoids } \\
\text { (5-hydroxy-7,3',4'- } \\
\text { tri-methoxiflavone) }\end{array}$ & Stem & $\begin{array}{l}\text { Antioxidant and } \\
\text { anti-proliverative }\end{array}$ & $\begin{array}{l}\text { Repeated extraction } \\
\text { with } \mathrm{MeOH} \text { and column } \\
\text { chromatographic } \\
\text { separation }\end{array}$ & [9] \\
\hline \multirow[t]{2}{*}{$\begin{array}{l}\text { Aquilaria } \\
\text { subintegra }\end{array}$} & Chloroform extract & $\begin{array}{l}\text { Leaves and } \\
\text { stem }\end{array}$ & $\begin{array}{l}\text { Acetylcholinesterase } \\
\text { (AChE) inhibitor }\end{array}$ & $\begin{array}{l}\text { Extraction with } \\
\text { chloroform solvent }\end{array}$ & [2] \\
\hline & $\begin{array}{l}\text { Ethanol, methanol, } \\
\text { and n-hexane } \\
\text { extracts }\end{array}$ & Fruit & Anticancer & $\begin{array}{l}\text { Extraction with } \\
\text { methanol, ethanol, and } \\
\text { n-hexane }\end{array}$ & [11] \\
\hline $\begin{array}{l}\text { Aquilaria } \\
\text { crassna }\end{array}$ & $\begin{array}{l}\text { Leaf ethanol extract } \\
\text { and mangiferin }\end{array}$ & Leaves & $\begin{array}{l}\text { Antioxidant, } \\
\text { antidiebetic, and } \\
\text { anticancer }\end{array}$ & $\begin{array}{l}\text { Soxhlet extraction using } \\
\text { ethanol and } \\
\text { identification of } \\
\text { compounds based on } \\
\text { TLC-densitometric }\end{array}$ & [14] \\
\hline
\end{tabular}

\section{Aquilaria crassna}

Aquilaria crassna or agarwood belongs to the flowering plant family Thymelaeaceae. According to Ray et al., (2014) [12] that this plant is well-known for its aromatherapy purposes and as a medicinal plant to cure some symptoms of inflammation, pain, fever, and constipation. Mangiferin is a xanthone derivative which is reported as one of the compounds isolated from Aquilaria crassna which has activities as a super antioxidant, anti-allergic, antidiabetic, anti-inflammatory and antibacterial [6]. In a study by Thitikompong et al., 2019 [14] which investigated the antidiabetic activity, antioxidant and cytotoxicity of the ethanol extract of Aquilaria crassna. The leaves of Aquilaria crassna were extracted with ethanol using a Soxhlet kit and identified the mangiferin content in the extract using the TLCdensitometric method.

In antidiabetic testing using alpha-glucosidase activity inhibition test with p-nitrophenyl$\beta$-D-glucopyranoside (PNPG) as a substrate. Mangiferin and leaf ethanol extract showed a stronger inhibitory effect of alpha-glucosidase activity than acarbose (control with activity and $17.3947 \pm 0.0189 \mathrm{mg} / \mathrm{mL}$ ) by means of a concentration response with each IC50 value of $0.5714 \pm 0,0044 \mathrm{mg} / \mathrm{mL}$ and $0.1840 \pm 0.0032 \mathrm{mg} / \mathrm{mL}$ [14].

The antioxidant activity was carried out based on the 2,2-diphenyl-1-picrihydrazyl (DPPH) test and the FRAP test, the reducing power was expressed in $\mu \mathrm{M}$ of iron sulfate which was equivalent in milligrams per dry weight of the sample. The results of the DPPH mangiferin test and the ethanol extract of Aquilaria crassna leaves, respectively, IC50 values were $0.64 \pm 0.005 \mathrm{mg} / \mathrm{mL}$ and $21.54 \pm 0.17 \mathrm{mg} / \mathrm{mL}$. This study implies that mangiferin and ethanol extract of leaves have potential as natural antioxidants through their phenolic properties in inhibiting RNS and ROS. Meanwhile, in the antioxidant test based on iron ion reduction (FRAP), where the antioxidant power of the ethanol extract of leaves and mangiferin is based on the reduction power of TPTZ-Fe ${ }^{3+}$ to $\mathrm{TPTZ}-\mathrm{Fe}^{2+}$ and the FRAP value 
obtained from the calculation of the ferrous sulfate calibration curve, respectively, is 11,82 $\mu \mathrm{M} \mathrm{Fe}(\mathrm{II}) / \mathrm{mg}$ and $2.52 \mu \mathrm{M}$ Fe (II) $\mathrm{mg}$ [14].

On the other hand, Aquilaria crassna was also reported by Thitikompong et al., 2019 [14] to have anticancer properties. Tests were carried out based on their cytotoxicity properties with the MTT test method and the relative number of cells was assessed by measuring the absorbance of the product at $570 \mathrm{~nm}$ with a micro plate reader. The test medium used human breast cancer cells (MDA-MB-231), human colorectal adenocarcinoma (HT-29), and human hepatocellular carcinoma (HepG2) from the American Type Culture Collection. In the study, the ethanolic extract of the leaves showed significant toxicity in all the cancer cell test samples. While mangiferin as a cytotoxic potential with cell viability of $100 \mu \mathrm{g} / \mathrm{mL}$ was $62.93 \%$ (MDA-231), 63.52\% (HT-29) and 67.85\% (HepG2).

\section{CONCLUSION}

The above mentioned review provides evidence that Aquilaria spp. many have interesting and useful potential in various applications in the medical field in improving human health. The review can also be useful for future studies and exploitation of various parts of the Aquilaria spp. potential as a treatment and prevention related to pharmacological fields.

\section{ACKNOWLEDGEMENTS}

This work is supported by the Biochemical Research Methodology courses. We thank Prof. Dr. Ir. I Made Artika, M.App.Sc, Faculty of Mathematic and Natural Science, Bogor Agricultural University.

\section{REFERENCES}

[1] Apridamayanti P, Sanera F, Robiyanto R. Antiinflammatory Activity of Ethanolic Extract from Karas Leaves (Aquilaria malaccensis Lamk.). Pharm Sci and Research. 5(3) (2018) 152-158. https://doi.org/10.7454/psr.v5i3.4094.

[2] Bahrani H, Mohamad J, Paydar M, Rothan H. A. Isolation and Characterization of Acetylcholinesterase Inhibitor from Aquilaria subintegra for the Treatment of Alzheimer's Disease (AD). Current Alzheimer Research. 11(2) (2014). https://doi.org/10.2174/1567205011666140130151344.

[3] Batubara R, Surjanto, Hanum TS, Handika A, Andi OF. The Screening of Phytochemical and Antioxidant Activity of Agarwood Leaves (Aquilaria malaccensis) from Two Sites inNorth Sumatra, Indonesia. Biodiverisitas. 21(4) (2020) 1588-1598. https://doi.org/10.13057/biodiv/d210440.

[4] Eissa MA, Hashim Y, Salleh HM, Abid-Azziz S, Md Isa L, Warif NMA, Nor YA, ElKersh DM, Sani MSA. Aquilaria Species as Potential Anti-inflammatory Agents-A Review on In Vitro and In Vivo Studies. Indian Journal of Natural Products and Resources. 11(3) (2020) 141-154.

[5] Eissa M., Hashim Y., Zainurin N. A. A. Aquilaria malaccensis Leaf as an Alternative Source of Anti-inflammatory Compounds. International Journal on Advanced Science Engineering Information Technology. 8 (2018) 4-2. https://doi.org/10.18517/ijaseit.8.42.7054 .

[6] Hashim YZHY, Kerr PG, Abbas P, Salleh HM. Aquilaria spp. (agarwood) as source of health beneficial compounds: A review of traditional use, phytochemistry and $\begin{array}{lllll}\text { pharmacology. } & \mathrm{J} & \text { Ethnopharmacol. } & 189 & \text { (2016) }\end{array}$ https://doi.org/10.1016/j.jep.2016.06.055.

[7] Jok VA, Che Radzi N, Ku Hamid KH. A Review: Pharmacological Properties of Aquilaria spp. Advanced Materials Research.1113 (2015) 193-197. https://doi.org/10.4028/www.scientific.net/AMR.1113.193. 
[8] Kumphune S, Prompunt E, Phaebuaw K, Sriudwong P, Pankla R, Thongyoo P. Antiinflammatory effects of the ethyl acetate extract of Aquilaria crassna inhibits LPSinduced tumour necrosis factor-alpha production by attenuating P38 MAPK activation. International Journal of Green Pharmacy. 2011. http://doi.org/10.22377/ijgp.v5i1.173.

[9] Liu CM, Perng MH, Chen CY. The Antioxidation and Antiproliferation Activity of Flavonoids from Aquilaria agallocha and Aquilaria sinensis. Biomedical Research. 29(10) (2018) 2191-2196. https://doi.org/10.4066/biomedicalresearch.29-18-333.

[10] Miniyar PB, Chitre TS, Karve SS, Deuskar HJ, Jain KS. Anti-oxidant activity of ethyl acetate extract of Aquilaria agallocha on nitrite induced methemoglobin formation. Int J Green Pharm. 2 (2008) 43-4. http://doi.org/10.22377/ijgp.v2i2.43.

[11] Nurhanan Y, Azah MAN, Zunoliza A, Humeriah AGS, Syarifah MS, Hayati AN. In Vitro Anticancer Activity and High-Performance Liquid Chromatography Profiles of Aquilaria Subintegra Fruit and Seed Extracts. Journal of Tropical Science 29(2) (2017) 208-214.

[12] Ray G, Leelamanit W, Sithisarn P, Jiratchariyakul W. Antioxidative compounds from Aquilariacrassna Leaf. Mahidol University J Pharm Sci. 41(4) (2014) 54-58.

[13] Sarveswaran R, Jayasuriya WA BN, Suresh TS. In Vitro Assay To Investigate The AntiInflammatory Activity of Herbal Extracts: A Review. World Journal of Pharmaceutical Research. 6(17) (2017). https://doi.org/10.20959/wjpr201717-10058.

[14] Thitikompong W, Palanuvej C, Ruangrungsi N. In Vitro Antidiabetic, Antioxidation and Cytotoxicity Activities of Ethanolic Extract of Aquilaria crassna Leaves and its Active Compound Mangiferin. Indian Journal of Traditional Knowledge. 18(1) (2019) 144-150. 